\title{
Convulsive therapy in Brazilian psychiatric practice
}

Convulsoterapias na prática psiquiátrica brasileira

Convulsoterapia en la práctica psiquiátrica brasileña

Jusley da Silva Miranda*(D); Juliana Cabral da Silva Guimarães**(D); Tatiana Marques dos Santos***(D);

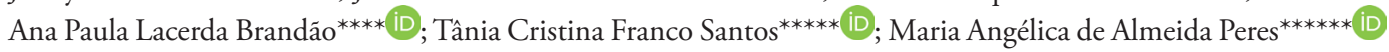

\section{Abstract}

Context: From 1920 to 40, traditional psychiatry in Brazil focuses on convulsive practices as an innovative treatment to reduce symptoms of mental illness.

Objective: To analyze the techniques of application of convulsive therapies disclosed in two major medical journals.

Methodology: Documental study, with a qualitative approach. The historical sources were the Brazilian Archives of Neurology and Psychiatry (ABNP) and the Annals of the Institute of Psychiatry (IPUB) from 1928 to 1947. Critical analysis was based on data triangulation and thematic organization.

Results: Twenty-seven publications were found in both journals. The publications were gathered in groups according to the techniques used [cardiazolic shock (14); malariotherapy (5); insulin shock (4); cardiazolic shock associated with insulin shock (2); electroconvulsive therapy (1); cardiazolic shock associated with electroconvulsive therapy (1)].

Conclusion: The journals had contributed to the dissemination of scientific development on the biological therapies, with the publishing of studies to guide their implementation. They aimed to establish correlations between mental illnesses, their symptoms, and the effects of each convulsive treatment technique, without any explicit reference to the participation of nursing professionals.

Keywords: convulsive therapy; electroconvulsive therapy; involuntary treatment, psychiatric; history of nursing

\section{Resumo}

Contexto: Nas décadas de 1920-40, a psiquiatria tradicional no Brasil apostava na prática de convulsoterapias como tratamento inovador para reduzir sintomas das doenças mentais.

Objetivo: Analisar as técnicas de aplicação de convulsoterapias em dois periódicos médicos.

Metodologia: Estudo documental, qualitativo, cujas fontes históricas foram os Arquivos Brasileiros de Neurologia e Psiquiatria (ABNP) e os Anais do Instituto de Psiquiatria (IPUB) de 1928 a 1947. Para análise crítica foi feita a triangulação dos dados e organização temática. Resultados: Foram encontradas 27 publicaçóes em ambos os periódicos. As publicaçôes encontradas foram agrupadas de acordo com as técnicas utilizadas [choque cardiazólico (14); malarioterapia (5); choque insulínico (4); choque cardiazólico associado ao choque insulínico (2); eletroconvulsoterapia (1); choque cardiazólico associado a eletroconvulsoterapia (1)].

Conclusáo: Os periódicos pesquisados contribuíam para a difusão do desenvolvimento científico sobre as terapias biológicas, publicando estudos que norteavam a sua aplicação, visando estabelecer um sentido entre as doenças mentais, os seus sintomas e os efeitos de cada uma das técnicas convulsivas de tratamento, sem mencionar explicitamente a participaçáo da enfermagem.

Palavras-chave: convulsoterapia; eletroconvulsoterapia; tratamento psiquiátrico involuntário; história da enfermagem

*Bachelor, Undergraduate Student, Federal University of Rio de Janeiro, Nursing School Anna Nery, Rio de Janeiro, 20211-110, Brazil [jusley.enf14@gmail.com]. O hitps://orcollection, treatment, and analysis; writing of the article.

**MSc RS , Federal University of Rio de Janeiro, Nursing Scol - MSc., RN, Federal University of Rio de Janeiro, Nursing School Anna Nery, Rio de Janeir Contribution to the article: data treatment and analysis.

***ntribution to the article: data treatment and analysis.

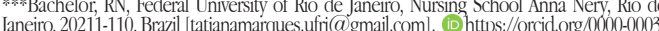
Janeiro, 20211-110, Brazil [tatianamarques.urr)@gmail.com]. (1) https://orcid.org/0000-0

081-6174. Contribution to the article: bibliographical research and writing of the article. Janeiro, 20211-110, Brazil [apclacerda $@$ gmail com] D https:/orcid.org/0000-0002-62553714. Contribution to the article: data treatment and analvsis.

3714. Contribution to the article: data treatment and analysis.

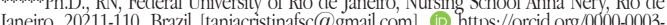
2325-4532. Contribution to the article: writing of the article.

*2325-4532. Contribution to the article: writing of the article. Janeiro, 20211-110, Brazil [angelica.psi@ uol.com.br]. D https://orcid.org/0000-0002-6430Janeiro, 20211-110, Brazil [angelica.psi@ @uol.com.br]. D https://orcid.org/0000-0002-0430pondence: Rua Padre Francisco Lana, 146/403, Vila Isabel, 20551-090, Rio de Janeiro, Brasil.

\section{Resumen}

Marco contextual: En las décadas de 1920-40, la psiquiatría tradicional en Brasil apostaba por la práctica de la convulsoterapia como tratamiento innovador para reducir los síntomas de las enfermedades mentales.

Objetivo: Analizar las técnicas de aplicación de la convulsoterapia en dos fuentes médicas.

Metodología: Estudio documental, cualitativo, cuyas fuentes históricas fueron los Archivos Brasileños de Neurología y Psiquiatría (ABNP) y los Anales del Instituto de Psiquiatría (IPUB) de 1928 a 1947. Para el análisis crítico se realizó la triangulación de los datos y la organización temática.

Resultados: Se encontraron 27 publicaciones en ambas fuentes. Las publicaciones encontradas se agruparon de acuerdo con las técnicas utilizadas [choque cardiazólico (14); malarioterapia (5); choque insulínico (4); choque cardiazólico asociado al choque insulínico (2); electroconvulsoterapia (1); choque cardiazólico asociado a la electroconvulsoterapia (1)]. Conclusión: Las fuentes utilizadas contribuyeron a difundir el desarrollo científico sobre las terapias biológicas, así como a publicar estudios que orientaban su aplicación con el objetivo de establecer un sentido entre las enfermedades mentales, sus síntomas y los efectos de cada una de las técnicas convulsivas de tratamiento, sin mencionar explícitamente la participación de la enfermería.

Palabras clave: terapia convulsiva; terapia electroconvulsiva; tratamiento psiquiátrico involuntario; historia de la enfermería

Received for publication: 08.11 .18

Accepted for publication: 21.03 .19 


\section{Introduction}

Psychiatry emerged as medical science in Brazil in the year of 1883 , resulting in the introduction of psychiatry as a subject in existing medical schools of the country. Religious nursing was responsible for the creation of the first mental asylum, established in Rio de Janeiro in 1852. The Sisters of Charity of St. Vincent de Paul, brought from France by the Santa Casa da Misericórdia of Rio de Janeiro, provided in this institution nursing care to psychiatric patients. At the end of the $19^{\text {th }}$ century and beginning of the $20^{\text {th }}$ century, a school for nurses, belonging to the asylum, began to train psychiatric care staff, supporting the laicization of this institution (Peres, Barreira, Santos, Almeida Filho, \& Barbosa, 2011).

The so-called biological therapies emerged in psychiatry during the 1910s and 1930s. Although at the time little was known about the mechanism of action of these psychiatric therapies, they were considered effective, and their practice was widely spread (Talerow, 2011).

Convulsive therapies were another type of treatment. Malariotherapy (or malaria fever therapy) was the first, created at the end of the 1910s. In the 1930s there was the Sakel method, known as shock therapy, insulin therapy, or insulin coma therapy, and the Meduna method, also known as cardiazolic shock or cardiazolotherapy. In 1938, electroconvulsive therapy (ECT) appeared, popularly known as electrical shock, convulsive electrical therapy, or electroshock. All these therapies triggered seizures, which resulted in a remission of mental disorder symptoms, leading to the belief that a cure was possible. At first, these therapies were tested and used for the treatment of progressive general paralysis and schizophrenia (Talerow, 2011).

Nurses being present in places of hospitalization and treatment of psychiatric patients allowed the implementation of convulsive therapies. For years, nurses and guards assured care provision and maintenance of the asylums' balance, thereby promoting the advancement of psychiatric medicine. Therefore, convulsive therapies also allowed the construction of knowledge for psychiatric nursing care since the procedures required the preparation of patients and care provision during and after their implementa- tion. Nurses have always accompanied psychiatrists in the treatment of people with mental illnesses, including participating in the practice of convulsive therapies.

Historical studies show that nursing practice in psychiatry evolved in Brazil within the mental institutions and that the absence of records is a problem that researchers must overcome. There is a lack of nursing records in Brazil during the study period.

At the end of the $19^{\text {th }}$ century, Brazilian medicine began changing its scientific paradigm and, thus, needed a means of scientific dissemination, resulting in the creation of medical journals as essential vehicles of research, intervention, and dissemination (Jacó-Vilela, Escch, Coelho, \& Rezende, 2004).

The studies related to convulsive therapies in psychiatric practice from the early $20^{\text {th }}$ century were considered innovative. They were, however, a rearrangement of the $19^{\text {th }}$-century health care system, which had been improving. At the time, scientific knowledge was regarded as a medical statement to society, that believed in science and knowledge of the causes of mental illness (Tarelow, 2011).

Consequently, medical knowledge evolved and ceased to be a practical discourse more focused on order and rules, becoming more scientific and more pathology-related. Scientific publications disseminated this knowledge, which transformed the psychiatric medical society with the integration of fundamentals into theoretical models of diagnosis and treatment of mental illness.

Convulsive therapies were used extensively in the treatment of mental illnesses in Brazil and addressed and discussed in the studied documents, of which the following stand out: malariotherapy; the Sakel method; the Meduna method; and electroconvulsive therapy. Given the importance of biological therapies for the evolution of psychiatric treatment, we formulated the following research question: How was convulsive therapy implemented in Brazil during the first half of the $20^{\text {th }}$ century? Based on this scenario, this study aims to analyze the techniques of convulsive therapy implementation disseminated in Brazil, in the first half of the $20^{\text {th }}$ century.

It is expected that the results of this study can expand the historical and scientific knowl- 
edge of convulsive therapies to understand the development of psychiatric care within the mental institution context, which ultimately condemned such practices because of how they were developed.

The relevance of the research topic lies on the absence of historical sources containing evidence of nursing care in convulsive therapies in the first half of the $20^{\text {th }}$ century, thus supporting research in medical sources, as medicine operates in the same arena as nursing. It is known that nursing care became a specialized practice as medical practices advanced, and that provided care is related to the social-historical context of that time, thereby supporting research in medical writings.

\section{Methodology}

We conducted a documental study with a qualitative approach, taking into account that this type of research "favors the monitoring of the process of maturation or evolution of individuals, groups, concepts, knowledge, behaviors, mentalities, practices, and so forth" (Sá-Silva, Almeida, \& Guindani, 2009, p. 2).

Research in the Brazilian Archives of Neurology and Psychiatry (Arquivos Brasileiros de Neurologia e Psiquiatria) focused on publications between 1919 and 1957, beginning at the dates corresponding to the journal's first and last issue with this title. In the Annals of the Institute of Psychiatry (Anais do Instituto de Psiquiatria), research was carried out in the period between 1942 to 1947 , from the first to the last issue published. Therefore, the timeline of this article begins in 1928 and ends in 1947, referring, respectively, to the year of the first and last publications on convulsive therapy, in both journals.

Data were collected in the second half of 2016, in two collections where prior internet research located selected journals for research: The $\mathrm{Na}$ tional Library Foundation (BN) and the Library of the Institute of Psychiatry of the Federal University of Rio de Janeiro (IPUB). There were three stages, namely: (1) Study of the collection including all journals, or the highest number of volumes of both journals; (2) Identification, in the abstracts of each volume, of articles whose title referred to convulsive therapy; (3) Reading the full texts for data selection. To point out that volumes corresponding to the year of 1926 of the Brazilian Archives of Neurology and Psychiatry were not available for consultation at the time of the research, so they were not included in this study.

Data collection was based on the analysis of the publications' titles, to identify articles which referred to convulsive therapy practices. In this phase, including original articles, book/journal reviews, and conferences, 27 publications were found in both journals: 19 in the Brazilian Archives of Neurology and Psychiatry and 8 in the Annals of the Institute of Psychiatry of the University of Brazil. The publications found in the Brazilian Archives of Neurology and Psychiatry were divided into two categories: original articles and book reviews and conferences, including, respectively, 16 and three studies. The sections referred to as Bibliography and Conference are the result of the analyses.

The studies, all written by physicians, were organized chronologically, according to each journal. The criteria used were the year, title, and section. The documents were characterized and gathered in groups by theme. After reading each publication carefully in full, we analyzed their contents based on the research objective and applied thematic analysis.

Data interpretation was based on triangulating the sources between them and with secondary sources involving these topics (Carter, Bryant-Lukosius, Dicenso, Blythe, \& Neville, 2014). The authors who wrote about the social and historical context of the study period also contributed to the interpretation.

\section{Results and Discussion}

In 1905, within the context of the Brazilian Academy of Medicine, the alienists Juliano Moreira and Afrânio Peixoto created the journal entitled Brazilian Archives of Psychiatry, Neurology, and Related Sciences, with the support and participation of physicians and lecturers from medical schools in several Brazilian states (Cerqueira, 2014). With ample collaboration from professionals, the journal became essential to the scientific profile of psychiatry.

Regarding the specialization of medical areas, in November 1907, the Brazilian Society of 
Neurology, Psychiatry, and Forensic Medicine (SBPNML) was established as a scientific body, contributing to the consolidation of psychiatric knowledge. In 1908, the Brazilian Archives of Psychiatry, Neurology, and Related Sciences became the official journal of SBPNML, changing its name to Brazilian Archives of Neurology, Psychiatry, and Forensic Medicine (Cerqueira, 2014). Later, a section was created for the publication of minutes of SBPNML meetings. From 1919 onwards, this journal began to circulate with the title Brazilian Archives of Neurology and Psychiatry (ABNP), as publications often focused on these areas (Facchinetti, Cupello, \& Evangelista, 2010).

The studies published by the ABNP referred to the period between 1928 and 1940 and mentioned the following convulsive therapies: cardiazolic shock (eight); malariotherapy (five); shock therapy (four); and cardiazolic shock associated with shock therapy (two). The most significant number of publications refers to the period 1938 - 1940, including 13 publications, as shown in Table 1 .

Table 1

Publications in the Brazilian Archives of Neurology and Psychiatry, between 1928 and 1940

\begin{tabular}{|c|c|c|}
\hline Year & Title & Section \\
\hline 1928 & A malarioterapia na paralisia geral & Review \\
\hline 1929 & Paralisia geral juvenil e malarioterapia & Review \\
\hline \multirow{2}{*}{1934} & Malarioterapia nas psicoses nấo luéticas & Original article \\
\hline & Malarioterapia & Bibliography \\
\hline \multirow{2}{*}{1936} & Choque insulínico no tratamento da esquizofrenia & Review \\
\hline & Malarioterapia & Review \\
\hline \multirow{4}{*}{1938} & Cardiazoloterapia dos esquizofrênicos & Original article \\
\hline & Sakel's pharmacologic shock treatment for schizophrenia & Review \\
\hline & Protamine zinc insulin - Its unsuitability for hypoglycemic shock therapy & Review \\
\hline & Tratamiento de la esquizofrenia con cardiazol a dosis convulsivante & Review \\
\hline \multirow{6}{*}{1939} & Aspeto subjetivo das convulsões cardiazólicas & Review \\
\hline & Tratamento da esquizofrenia e estados afins pelo Cardiazol em doentes indianos & Review \\
\hline & $\begin{array}{l}\text { Experiências comparativas sobre o tratamento da esquizofrenia pela insulina e pelo } \\
\text { cardiazol }\end{array}$ & Conference \\
\hline & Estudos eletrocardiográficos no tratamento da esquizofrenia pelo cardiazol & Review \\
\hline & Estudo médico-legal dos esquizofrênicos insulinizados e cardiazolizados & Review \\
\hline & Psiconeurose de angustia, cardiazol e psicoterapia & Original article \\
\hline \multirow{3}{*}{1940} & Epilepsia consecutiva a tratamento pelo cardiazol & Review \\
\hline & Complicações no tratamento da esquizofrenia pelo método de Sakel & Review \\
\hline & $\begin{array}{l}\text { Um caso de histeria sugerida pela supressão da masturbação e curada pelo choque } \\
\text { cardiazolico }\end{array}$ & Review \\
\hline
\end{tabular}


The Annals of the Institute of Psychiatry (AIP) emerged within the context of the creation of the University of Brazil, in 1920. The articulation between professional education and research was reinforced, seeking the development of original scientific studies on the national panorama (Sá, 2006). One of the milestones for the practice of teaching and research in psychiatry was the creation of the Institute of Psychiatry of the University of Brazil (IPUB), by Decree-Law No. 591 of 1938. Professor Henrique Britto de Belford Rôxo from the National Faculty of Medicine was the first director of IPUB and was its manager until 1945 when he retired.

The AIP were published between 1942 and 1947, including four issues. Despite its editor's initial intention to publish at the end of each year the works completed during that year, the sources reveal that, due to his retirement, the 1944 and 1945 editions were published jointly in 1947. Likewise, the 1946 and 1947 editions were published jointly in 1948 due to the accumulation of workload of the national press. After the editor's retirement, the IPUB administration was handed to the full professor of clinical psychiatry Mauricio Campos de Medeiros. From 1949 onwards, the official journal of the Institute of Psychiatry was renamed the Brazilian Journal of Psychiatry (JBP), giving continuity to the AIP.

Table 2 shows all the sources found in the AIP. To emphasize that they are all complete original studies, carried out at the institute. The studies produced and published in these Annals took place in the 1940s and referred to cardiazolic shock (six); ECT (one); cardiazolic shock associated with ECT (one).

Table 2

Publications in the Brazilian Archives of Neurology and Psychiatry, between 1928 and 1940

\begin{tabular}{ll}
\hline Year & Title (all original articles) \\
\hline \multirow{2}{*}{1942} & Alguns aspectos bioquímicos da convulsão cardiazólica (primeira contribuição) \\
\cline { 2 - 2 } & Alguns aspectos bioquímicos da convulsão cardiazólica (segunda contribuição) \\
\hline \multirow{2}{*}{1943} & O método de Meduna na psicose maníaco-depressiva \\
\cline { 2 - 2 } & A Convulsoterapia pela picrotoxina associada ao cardiazol, no tratamento das doenças mentais \\
\hline & $\begin{array}{l}\text { Aperfeiçoamento na terapia das doenças mentais pelo cardiazol } \\
\text { pelo cardiazol }\end{array}$ \\
\cline { 2 - 2 } & Estudos sobre a natureza do choque produzido por Cardiazol \\
\hline $1946 / 1947$ & Da Hipnoconvulsão químico-elétrica \\
\hline
\end{tabular}

\section{Malariotherapy}

Progressive general paralysis (PGP), a condition included in this study because of neurosyphilis, can manifest itself through different psychiatric symptoms, such as dysarthria, hallucinations, and motor impairment. During the late $19^{\text {th }}$ century and the first half of the $20^{\text {th }}$ century, PGP was seen as a step forward in this medical specialty, due to the knowledge of its etiologic agent, deeming it the illness of the century (Talerow, 2011; Tsay, 2013).

In 1883, through observations and readings, Jauregg raised the hypothesis of psychiatric nosotherapy, that is, the treatment of an illness with another. In other words, it was believed that an infection could create the necessary conditions to achieve significant improvements within the context of PGP. After several studies, in 1917 Plasmodium vivax was inoculated in nine patients, of which six had significant improvements (Tsay, 2013).

Syphilis had become a matter of public health in Brazil, since it affected the working class and overcrowded the health care services in urban centers (Tsay, 2013).

Studies show that malariotherapy was first used in 1924 in the Juliano Moreira Colony in Rio de Janeiro, the federal capital of Brazil at the 
time. This record was available in the annual report delivered by Juliano Moreira to the Minister of Justice and Internal Affairs. The first publication found on malariotherapy dates from 1928 (Accorsi, 2015).

Of all the analyzed publications on this convulsive treatment practice, four are available in the analysis section. We noted that three are summaries of Brazilian studies published in other journals. These authors reinforce malariotherapy as a universally adopted, safe, and effective technique for the treatment of PGP, as shown by the research results of Santos (1936), when referring to "the amazing improvements given to patients in general by malariotherapy, its indications and contraindications, routes of Plasmodium introduction, and so forth" (p. 22). There is also a review of the book Malarioterapia written by Waldemiro Pires, published in 1934, where:

The author faces the problem and its important practical consequences globally; he writes its meticulous historical record; safely explains technical facts; establishes the comparative framework of malariotherapy within general paralysis. The mechanism of action is revealed, and in this particular case, the author explains the current doctrines. (Freitas, 1934, p. 46)

It is necessary to emphasize that Pires built his medical career in neuropsychiatry and studied malariotherapy. He also developed research at the Pedro II Hospice and the Gaffrée and Guinle Foundation Hospital, resulting in significant contributions, including the abovementioned book (Accorsi, 2015).

It is noteworthy that, although malariotherapy was used for other purposes besides the PGP, the study by Pires (1929) provides evidence that the results were not very encouraging regarding technique efficiency. In a publication, we verify that "malariotherapy provides not many encouraging results in juvenile general paralysis. However, we believe that it should be attempted when dealing with an expansive form, which is rare in youngsters". (Pires, 1929, p. 125).

Also, a text in the section of original articles was published in 1934, also by Pires, where he writes about the use of malariotherapy in non-syphilitic psychoses. The author makes a review of international studies and practi- cal experiences, showing that the treatment with Plasmodium vivax does not provide significant results in comparison with other treatments already used, therefore recommending the use of this method only for PGP.

We identified two deficiencies among the publications found: only one publication discusses the treatment's mechanism of action, highlighting not accurately the conclusions of other authors on the same subject; and relating to the use of technique and care.

However, Accorsi (2015) presents the first protocol developed by Jauregg, which includes the following steps: (1) inoculating Plasmodium vivax in the patient by means of subcutaneous injections; (2) awaiting febrile states (between seven and 12) until the quota of convulsive crises deemed necessary by the doctor is achieved; (3) administering $1 \mathrm{~g}$ of quinine bisulphate each day, for three days, and then $0.5 \mathrm{~g}$ for the next 15 days; (4) finally, administering three doses of Neosalvarsan intravenously once per week. The described technique suggests that nursing had a role in this practice since the latter depended on procedures commonly belonging to the nursing area, such as injections, medication administration, and observation of febrile states. Moreover, convulsive seizures required professionals to restrain the patient, to avoid damaging accidents during the tonic and clonic phases. There is no reference to nurses in the documents addressing malariotherapy.

In the 1930s, the disadvantages, contraindications, and consequences of malariotherapy became the focus of debates, namely in medical journals. The last publication found on the topic is from 1936. However, the disappearance of the topic from journals does not mean the practice was abandoned or ceased to be a study theme. Even with the advent of penicillin in 1940, malariotherapy continued to be used along with antibiotherapy. It is known that the first study published in the federal capital about the use of penicillin in the treatment of PGP occurred in 1956 (Accorsi, 2015).

\section{Sakel Method}

The Sakel method was based on the monitoring of patients in alcohol and drug withdrawal. Their withdrawal symptoms diminished as they suffered hypoglycemia. Thus, these results were associated with a possible treatment for schizo- 
phrenia. After the tests, patients with schizophrenia manifested significant improvements. Sakel believed he had discovered the treatment for schizophrenia without any knowledge of the illness's physiology, meaning an opportunity for progress in research in the nature of psychic pathologies (Sakel, 1937).

In the analysis section of the four studies found in the ABNP, we could define some characteristics related to indications, care, technique, and some criticism about the method. With one exception, the analyses are a result of texts published in American journals, evidence of the internationalization of Brazilian physicians. The purpose of finding the cure for psychiatric illnesses was mentioned when supporting insulin therapy:

Insulin has been used for several mental illnesses, using a similar method as in general medicine. Sakel introduces a new route of employment, at first for morphinism and then for schizophrenia and the forms of maniacal behavior. The objective of the cure or favorable results was achieved with the administration of high doses of insulin to trigger the hypoglycemic shock, such as coma and convulsion. (Freitas, 1936, p. 21)

Regarding care before and during the procedure, we can point out: (1) clinical and electrocardiographic examinations; (2) checking blood glucose, blood pressure, weight, and collecting urine samples for analysis, before, during and after the procedure; (3) feeding can be made through a nasogastric tube, with egg whites, four times a day (Freitas, 1936).

Concerning the initial technique presented to the scientific community, we can list: (1) Injecting 15 to 50 units of insulin (IU) each day and increasing from 15 to 20 IU daily, until reaching the shock dose, which can be between 5 to $450 \mathrm{IU}$, depending on the patient; (2) Deep coma is expected for four to five hours with areflexia. The procedure can be carried out three to six times per week until the expected results are reached; (3) After manifestations of shock, one to three days of rest per week are allowed; (4) In chronic cases rest can be omitted. Giving sugar is recommended in doses proportional to the amount of insulin until the patient reaches a state of coma with negative corneal reflex and positive Babinski reflex (Sakel, 1937).

The description of the Sakel method also identifies nursing-related techniques, but it does not mention the professionals of this area, which proves their invisibility in the records of that period.

We can claim, based on sources, that the Sakel method was a revolutionary and widely used treatment for schizophrenia. However, there has always been criticism, mainly concerning the method's safety.

Some adaptations of the Sakel method stand out, such as the replacement of insulin with protamine zinc insulin because it is a compound with a 24 to 48 -hour action and slower glycemic fall. However, it was agreed that it would not be a viable replacement due to the difficulty of defining a precise dosage. An association of both was considered as well, but the result was severe hypoglycemia (Freitas, 1938).

Subsequently, there were comparative studies between the Sakel and Meduna methods. It should emphasized that Meduna devoted himself to understanding the mechanism of action of shock and cardiazolic shock therapies. In fact, among these studies, on their visit to Brazil in 1939, Meduna and Rohny presented at the SBPNML the conference Comparative experiences on insulin and cardiazol treatment of schizophrenia, aimed at researching the mechanism of action of both therapies.

Within this period, we note that publications regarding the Sakel method ceased to appear in 1940, which meant more opportunities to discuss cardiazol. Nevertheless, this method did not become obsolete and, also, authors still refer to the joint application of both methods.

\section{Meduna Method}

The creation of the Meduna method resulted from the monitoring of a possible biological antagonism between schizophrenia and epilepsy. It was found that: "Therefore, provided that it is possible to trigger epileptic seizures in patients with schizophrenia, these attacks will alter the clinical and humoral processes of the body, making it an unfavorable environment for the development of schizophrenia and creating the possibility of a biological cure for this illness" (Botelho, 1938, p. 70).

In short, the technique can be described as fol- 
lows: with dorsal decubitus patient positioning, administer three to five cc of $10 \%$ cardiazol by intravenous or intramuscular injection with a high gauge needle, preferably in the upper limbs, and wait for the convulsive crisis, occurring in the majority of patients within five minutes and, if it does not occur, administer five more cc of cardiazol within two minutes (Botelho, 1938).

The crisis occurs in the form of an epileptic seizure, manifesting itself at first with the loss of consciousness, within 10 to 20 seconds after the injection; followed by tonic contractions, lasting from 5 to 30 seconds; and then the generalized clonic seizures, lasting from 20 to 50 seconds. After the crisis, the patient falls asleep, on average, for five minutes and wakes up, many times, in an agitated state (Botelho, 1938).

Within this period, the most studied therapy was the Meduna method. The first completed study is published in 1938 , as a result of research already developed in Brazil. Sources show that this technique had been widely used in the country, even after the appearance of the ECT. The texts found in the analysis section have different origins, from European to South American countries, allowing us to reflect on the references used by Brazilian authors. On the whole, these texts are an analysis of researches about cardiazol use and its variations, such as myocardial lesions; the correlation between schizophrenia and epilepsy; perception of patients about treatment with this technique; and encouraging therapy results, namely in cases of schizophrenia.

We noted that the steps of preparation of the patient after the procedure have been adjusted over time. Alterations were made according to the scientific development included in international literature which supported researches of Brazilian authors:

To receive the cardiazol injection, patients must be fasting and not under the influence of any sedatives of the nervous system ... when receiving the injection, they must be lying down, with all clothing completely undone. An assistant will prepare a soft pad or like we do, a folded napkin to insert in the patient's mouth at the opportune moment, so dislocation of teeth can be avoided when the patient suddenly flexes the jaw. (Botelho, 1938, p. 42)

An assistant is mentioned in this excerpt, possibly a nurse, since his/her function is inserting a mouth guard in the patient to avoid injury during epileptic seizures. Once more, nursing activities are described, yet, there is no reference to professionals of this area.

Of the studies on the adaptation of cardiazol use, three stand out: the first discusses cardiazol in psychoanalysis for the treatment of anguish neurosis; the second associates picrotoxin with cardiazol, aiming to verify if properties of the former reduce cardiazol's unwanted effects on convulsive crisis; and the third addresses the associated use of glucose solution and cardiazol to decrease the intensity of seizures.

\section{Electroconvulsive therapy}

As far as we know, ECT was brought to Brazil in 1941 by Antonio Carlos Pacheco e Silva, a psychiatry professor at the University of São Paulo, via United States (Rosa, 2007). In this study, it was noted that the first comparative study between cardiazolic and electrical shocks was conducted in 1943. Developed in the IPUB, this complete study discusses and analyzes their differences, particularly: "Moreover, we assume that the crisis induced by the ECT is less intense than that triggered by cardiazol. Another interesting detail is that the pre-convulsive period is less painful in electroconvulsive therapy" (Souza, 1943, p. 234).

Pacheco and Silva, in 1941, highlighted some advantages in the use of ECT to the detriment of cardiazol treatment, which are: simple and cheap treatment; no pain, minimal discomfort, and complete amnesia after sessions; smaller seizures than in cardiazolic shock; lower frequency of fractures and dislocations; recovery after initiating treatment; absence of parenteral medication (Rosa, 2007).

Patient preparation for the ECT has some similarities to the Meduna method, such as: conducting general tests to check for contraindications; washing the head on the day prior to the procedure; suspending the use of sedatives, antispasmodics, and other seizure inhibitors; fasting; wearing comfortable clothes, removing ornamental objects and metal objects (Souza, 1943).

Recommendations about the environment 
and application of the technique stipulated that the ground should be covered with insulating material and the bed made of wood. The technique consisted of: (1) measuring the resistance of the patient's head; (2) applying an electricity conductive paste or a gauze soaked in $20 \%$ sodium chloride on the electrodes; (3) delivering the shock with a mean duration of 2 to 5 seconds, with an intensity of 200 to 300 $\mathrm{mA}$. It must be emphasized that the duration and intensity varied depending on the model of the ECT device (Souza, 1943).

Although the research documents held no such records, studies show that the physician delivered the electrical shock, but the nursing team prepared the patient for the procedure. Before the ECT, the nurse monitored the patient's fasting, kept his/her hair clean and dry, and inserted the mouth guard. During the ECT, the nurse held the patient so that no falls or musculoskeletal injuries occurred during the tonic-clonic crisis and, after the ECT, the nurse had to check the patient's vital signs, feed him/ her, and monitor his/her time/space orientation skills (Guimarães et al., 2018).

Since its creation in 1934, ECT's technique has undergone numerous modifications, of which the most considered is the mandatory use of short-duration anesthesia, promoting unconsciousness in the pre-convulsion period and partial muscle relaxation, avoiding fractures and muscle aches. Despite all the questions about its efficacy and safety and the appearance of psychiatric drugs in the 1950s and other therapies, ECT is still used in many countries. In Brazil, although the psychiatric reform movement considers ECT a manicomial practice, this technique was not prohibited and is regulated by Resolution of the Federal Council of Medicine no. 1,640/2002.

\section{Conclusion}

The sources analyzed allow establishing a correlation between the creation of the ABNP and the country's process of modernization, resulting in the specialization of medical knowledge and the evolution of psychiatry as a science. The internationalization of Brazilian authors is evident as well, as we can see from the texts published in the analysis section and the ref- erences used to support researches developed in the country.

It must be emphasized the importance of the creation of the University of Brazil and the IPUB for the development of new studies and publications, as the Annals of the IPUB disseminated the new scientific knowledge produced within the institution.

Despite their empirical development, malariotherapy and the other biological therapies analyzed in this study were the results of the efforts of medicine to cement psychiatry as medical science, while researching the correlation between mental disorders and their organic causes.

During this period, it is noted that, despite the emergence of new therapies, the old techniques did not become immediately obsolete and, in fact, continued to be used and tested in different ways in nursing homes.

It is important to highlight that all texts were written by physicians, although we can conclude that the implementation of convulsive therapy techniques required the support of other professionals, namely nurses. The absence of direct references to these professionals in the texts can be explained by the historical context involving these professions.

\section{References}

Accorsi, G. E. (2015). Entre a moléstia e a cura: A experiência da malarioterapia pelos psiquiatras do Rio De Janeiro (1924-1956) (Master's Dissertation). Casa de Oswaldo Cruz, Rio de Janeiro, Brasil.

Botelho, A. (1938). Cardiazoloterapia dos esquizofrênicos. Arquivos Brasileiros de Neurologia e Psiquiatria, 21(3-4), 69-86.

Carter, N., Bryant-Lukosius, D., Dicenso, A., Blythe, J., \& Neville, A. J. (2014). The use of triangulation in qualitative research. Oncology Nursing Forum, 41(5), 545-547. doi:10.1188/14.ONF.545-547

Cerqueira, E. C. (2014). A Sociedade Brasileira de Neurologia, Psiquiatria e Medicina Legal: Debates sobre ciência e assistência psiquiátrica (1907-1933). (Master's Dissertation). Casa de Oswaldo Cruz, Rio de Janeiro, Brasil.

Facchinetti, C., Cupello, P., \& Evangelista, D. F. (2010). Arquivos Brasileiros de Psiquiatria, Neurologia e Ciências Afins: Uma fonte com muita história. História, Ciências, Saúde - Manguinhos, 17(2), 527-535.doi:10.1590/ S0104-9702010000600015 
Freitas, M. (1934). Malarioterapia. Arquivos Brasileiros de Neurologia e Psiquiatria, 18(1), 45-46.

Freitas, M. (1936). Choque insulínico no tratamento da esquizofrenia. Arquivos Brasileiros de Neurologia e Psiquiatria, 19(1), 21.

Freitas, M. (1938). Análise: Moersch F., \& Kernohan J. W. Protamine zinc insulin: Its unsuitability for hypoglycemic shock therapy. Arquivos Brasileiros de Neurologia e Psiquiatria, 21(3-4), 124-125.

Guimarães, J. C., Santos, B. L., Aperibense, P. G., Martins, C. S., Peres, M. A., \& Santos, T. C. (2018). Eletroconvulsoterapia: Construção histórica do cuidado de enfermagem (1989-2002). Revista Brasileira de Enfermagem, 71(Supl. 6), 2743-2750. doi:10.1590/00347167-2018-0168

Jacó-Vilela, A. M., Esch, C. S., Coelho, D. A., \& Rezende, M. S. (2004). Os estudos médicos no Brasil no Século XIX: Contribuiçóes a psicologia. Memorandum, 7 , 138-150. Retrieved from http://www.fafich.ufmg. br/ - memorandum/artigos07/artigo09.pdf

Peres, M. A., Barreira, I. A., Santos, T. C., Almeida Filho, A. J., \& Oliveira, A. B. (2011). O ensino da psiquiatria e o poder disciplinar da enfermagem religiosa: O hospício de Pedro II no segundo reinado. Texto \& Contexto Enfermagem, 20(4), 700-8. doi: 10.1590/ S0104-07072011000400008

Pires, W. (1929). Paralisia geral juvenil e malarioterapia. Arquivos Brasileiros de Neurologia e Psiquiatria, 21(1), $124-125$.

Sá, D. M. (2006). A ciência como profissão: Médicos, bacharéis e cientistas no Brasil (1895-1935). Rio de Janeiro, Brasil: Fiocruz. doi: 10.7476/9788575413081.

Sakel, M. (1937). The methodical use of hypoglycemia in the treatment of psychoses. American Journal of Psychiatry, 94(1), 111-129.

Santos, A. M. (1936). Malarioterapia. Arquivos Brasileiros de Neurologia e Psiquiatria, 19(1), 22.

Sá-Silva, J. R., Almeida, C. D., \& Guindani, J. F. (2009). Pesquisa documental: Pistas teóricas e metodológicas. Revista Brasileira de História \& Ciências Sociais, 1, 1-15. Retrieved from https://www.rbhcs.com/rbhcs/article/ download/6/pdf

Souza, F. A. (1943). Convulsoterapia pela picrotoxina associada ao cardiazol, no tratamento das doenças mentais. Anais do Instituto de Psiquiatria, (2), 234-277.

Rosa, M. (2007). Pacheco e Silva and the origins of electroconvulsive therapy in Brazil. The Journal of ECT, 23(4), 224-228. doi: 10.1097/yct.0b13e318155984d

Talerow, G.Q. (2011). Entre febres, comas e convulsöes: as terapias biológicas no Hospital do Juquery administrado por Pacheco e Silva (1923-1927). (Master's Dissertation). Universidade de São Paulo, São Paulo, Brasil.doi: 10.11606/D.8.2012.tde-18052012-115937

Tsay, C. (2013). Julius Wagner-Jauregg and the legacy of malarial therapy for the treatment of general paresis of the insane. The Yale Journal of Biology and Medicine, 86, 245-254. Retrieved from https://www.ncbi.nlm. nih.gov/pmc/articles/PMC3670443/ 